\title{
Learner Attitude towards EFL Learning: A Response from Art and Design
}

\author{
Amina Asghar, Iqra Jamil, Afeefa Iqbal, Musarat Yasmin \\ Department of English, University of Gujrat, Gujrat, Pakistan \\ Email: musaratalvi@hotmail.com
}

How to cite this paper: Asghar, A., Jamil, I., Iqbal, A. and Yasmin, M. (2018) Learner Attitude towards EFL Learning: A Response from Art and Design. Open Journal of Social Sciences, 6, 81-88. https://doi.org/10.4236/jss.2018.65007

Received: April 4, 2018

Accepted: May 13, 2018

Published: May 16, 2018

Copyright $\odot 2018$ by authors and Scientific Research Publishing Inc. This work is licensed under the Creative Commons Attribution International License (CC BY 4.0).

http://creativecommons.org/licenses/by/4.0/

(c) (i) Open Access

\begin{abstract}
The study is conducted to evaluate the attitudes of the students of University of Gujrat towards ESL about emotional, behavioral and cognitive factors. It is also investigated what attitudes students show towards ESL regarding their gender. There were 158 (95 females and 63 males) students from three different departments including Fine Arts, Design, and Architecture. The questionnaire is used as an instrument that contains 30 items to meet our goal. Findings reveal that the students of the University of Gujrat have a negative attitude to learn English as a second language. Moreover, gender has no such effect on attitude because there is no significant difference between male and female attitude towards ESL.
\end{abstract}

\section{Keywords}

Learner Attitude, Communication Skills, Emotional Factors, Behavioral Factors, Cognitive Factors

\section{Introduction}

"Language learning is considered as the keystone of human survival. As language can state our opinions, hopes and even our dreams." [1]. Some factors such as motivation, attitude, anxiety, learning achievements, aptitudes, intelligence, age, and personalities influence the learning process. The most important factor that influences on language learning is learners' attitudes [2]. The objective of present study is to demonstrate the concept of attitude as one of the key features of learning the English language as second language. Moreover, this study particularly examines the attitudes of the students of Fine arts, Design, and Architecture from the University of Gujrat (UOG) towards learning ESL considering three factors of attitude i.e., behavioral, emotional and cognitive. Also, this study investigates the effect of learners' demographic profile i.e., age, gender, medium of 
previous education and mother tongue on their attitudes regarding learning ESL. Reference [3] argued, "Opinion and beliefs have a significant effect on learners' attitudes towards learning English as a Second language." Positive belief leads to a positive attitude towards ESL, and negative beliefs would lead to the negative attitude.

\section{Literature Review}

The English language has become the most powerful language all over the world. Most of the countries with their own languages have picked up English as a foreign language [4]. These countries adopted the English language as their official language to meet their economic needs at the global level. The English language is extremely used in educational institutions as well. Language learning is highly influenced by learners' attitude and motivation.

Attitude is defined as "A psychological tendency that is expressed by evaluating a particular entity with some degree of favor or disfavor" [5]. Moreover, Reference [6] said, from last 50 years works on language attitude has been conducted to show the relation of the significant use of language and individual attitudes. Learning a second language does not only depend upon language learning method but on learners' attitude towards it. According to reference [7] attitudes to any language in the world are vital in its restoration, preservation, decay or death. The language attitude is what natives of various languages show towards other languages and also towards' their own language. Language attitude also indicates the state of mind of the people towards that particular language. Optimistic attitude towards the second language would lead the successful learning of the second language. If learners would not communicate with the native speakers of the target language, they would have a pessimistic attitude and not learn the target language conveniently.

Learning criteria brings more positive alternations in the persons' attitude, about emotional, behavioral and cognitive fields, because when a person learn a particular subject, he is expected to behave in a quite in a different way than others. Moreover, learning criteria has social and behavioral aspects in comparison to cognitive approach. All three fields have particular features regarding the outcome of language attitude. All these fields are briefly described in the below.

Behavioural aspect refers to the way in which a learner behaves in specific conditions. Positive language learning helps the learner to classify themselves to a native of that language and implement the behavioral aspects that distinguish the target language members. According to reference [3], positive attitude fosters positive behavior towards studying. Such learners are witnessed to demonstrate more eagerness to resolve problems and to involve themselves emotionally.

Cognitive aspect of attitude includes the inclination of the subjects regarding information which they learn and the comprehension in the method of language learning. The cognitive aspect can be categorized into four steps connecting the 
previous knowledge and the new one, creating new knowledge, checking new knowledge and applying the new knowledge in many situations.

Whereas emotional aspect is concerned, reference [8] stated that learning process is an emotional process influenced by several factors. It helps to specify the liking and disliking of the learners. The Inner state of mind affects the attitude of learner regarding foreign language.

A number of studies across the world have been conducted on attitudes towards language learning. Such as reference [9] set out a study on 196 students of Applied Technology High School (ATHS) during the session of 2010-11. The purpose of this study was to discover the attitude of learners towards English language and also evaluate teacher's conception in term of attitude. This work reveals that $48.47 \%$ learners have a positive attitude and $51.53 \%$ have the moderate attitude to learn ELL. No one found to have negative attitude towards English Language learning. Besides this, results also discovered that students' positive alignment towards the English language did not effect by the instructors' conception rather than by the learning techniques and environment. Attitude can be changed by several factors like effective language schooling tactics can encourage the students to learn the English language. Reference [10] investigated attitudes of 238 undergraduate learners towards ESL learning at Public University in Malaysia. The findings underlined that the students are more aware of their goals about language learning that lead to high attitudes of learners. Even though they have English courses in their academics but they want to have more attention regarding their learning. It also focused on the reasons that may encourage or discourage the students' attitudes. Teachers can also influence the course of events in students' favor. According to reference [11], instructors' main tasks are to provoke curiosity and participation in the subject when they do not have interest in the related course. Another study of reference [12] also determined the attitude of the students of Kashan University. A powerful learning and attitude is seen due to the effect of gender, fields, and year of study. The main purpose of this study is to examine the attitude of undergraduate male and female learners of English as a foreign language. Both male and female have an optimistic attitude regarding ESL but the female have a more positive attitude than males. This study negates the study of reference [13] that investigates all aspects of the attitude of secondary school students who were not interested in learning English language. Their research was based on 180 students (94) males (86) females from different secondary schools in the division of Al Mergeb, Zliten in the west of Libya. English language attitude in term of three aspects between learners is mean score (2.6167) that leads negative attitude. Their negative attitudes show that they do not have awareness about the significance of English language. Another reason for negative attitude teaching methods may not be well developed. They also explored the differences based on demographic profiles (gender, field and year of study) in his research. Statistically significant differences in attitudes were found about gender and year of study but not about 
year of study. Reference [14] work on Libyan students showed that due to the strong influence of L1, students have deprived inspiration and pessimistic attitudes towards ESL. Poor acceptance of English in the Libyan nation is due to lack of motivation and negative attitude of both teachers and students towards that language. Study of reference [15] consisted of 123 students of Tehran High Schools in the East. It reports that the female learners of Tehran High School Students are closer to L2 than male learners. They considered the English language is adding new knowledge to their existing knowledge. This study emphasizes on two types of motivation i.e. instrumental and integrative. While regarding gender factor, reference [2] found no significant difference in learners' attitudes towards learning English.

Above review showed that most of the studies were conducted in non-native countries of the world including Malaysia, Iran, and Libya with learners of high school, business and marketing. Besides, researchers observed that students of Fine Arts in UOG do not show an interest in learning a foreign language, particularly as a core subject. Though English language serves as official and academic language in Pakistan [16] [17], their teachers reported them more interested in their practical work: drawings, sketches, designing, etc. An absence of any such study conducted with students of arts motivated researchers to examine these learners' attitudes towards learning English and present study intends to fill this gap by asking the following question.

1) What are the attitudes of Arts students towards learning the English language about behavioral, cognitive and emotion aspects?

2) What is the significant difference between male and female students' attitude towards English as Second Language?

\section{Research Design}

The research design of this study is quantitative by nature. The adopted instrument is questionnaire used to evaluate learners' attitude towards the English Language. The sample was mandatory to attempt this questionnaire according to their own vision in relation to emotional, cognition and behavioral attitudes.

\subsection{Method of Data Collection}

The population of current study included all students (578 students) of School of Architecture Design and Arts (SADA) of UOG. 128 students ( 16 to 21 years of age and also non-native speakers) were selected as a sample comprising $65 \mathrm{fe}$ males and 63 males. The sample was selected from three sub-departments of SADA: Fine Arts (14), Design (92) and Architecture (22) of the first semester. An attitude questionnaire designed by reference [12] was adopted for the present study. It consisted of 30 items which were related to an emotional, cognitive and behavioral aspect of attitudes. Ten items were indicating behavioral, ten emotional and remaining ten were related to cognitive attitude. Of the total items, 18 were positive and 12 negative. All items were put in a 5-point Likert scale from 
level 1: Strongly Agree to level 5: Strongly Disagree. The survey was administrated during classes to ensure $100 \%$ results rate. All participants deliberately participated in the survey. Their answers to the questionnaire were evaluated in term of descriptive and inferential statistics.

\subsection{Method of Data Analysis}

All the questions were investigated in term of learners' attitude towards the English Language. For further analysis of data SPSS software used aiming to answer the research questions quantitatively. Independent sample T-test and one sample T-Test are also applied for descriptive analysis. 90 mean score is considered as a neutral response, and less than 90 mean score shows negative results and more than 90 shows positive results.

\section{Results and Discussion}

The result of first research question by applying the One-Sample T-test shows an overall mean score of students' attitudes as shown in Table 1.

It reveals that the students have a negative attitude towards learning the English language. Mean score (78.2215) is less than 90 that is insignificant. Furthermore, the mean scores of three aspects of attitude as revealed in Table 2 show behavioral aspect (26.2343), cognitive aspect (24.8799), and emotional aspect (27.1076). The difference between these three aspects is insignificant because no noteworthy difference. Moreover, learners of Architecture were found least positive about learning English (mean-76.07) as compared to those of Fine Arts and Design with their mean score 79.54 and 78.15 respectively.

\section{Learner Attitude and Gender}

As for as the second question is concerned, this study examined the attitudes of male and female students of UOG. Learners' attitudes on the base of gender are shown in Table 3.

As mentioned above mean score of males (80.8871) is slightly higher than females (76.4421). Thus, gender does not influence the attitudes of the students

Table 1. Attitudes of male and female learners.

\begin{tabular}{cccc}
\hline & $\mathrm{N}$ & Mean & Std. Deviation \\
\hline Sum & 128 & 78.2215 & 12.83537
\end{tabular}

Table 2. Behavioural, cognitive and emotional attitudes of male and female learners.

\begin{tabular}{cccc}
\hline Aspects & $\mathrm{N}$ & Mean & Std. Deviation \\
\hline Behavioral & 128 & 26.2343 & 5.40742 \\
Cognitive & 128 & 26.1456 & 5.71603 \\
Emotional & 128 & 26.1962 & 5.95895 \\
\hline
\end{tabular}


Table 3. Attitudes of male and female learners.

\begin{tabular}{cccc}
\hline Gender of Respondents & N & Mean & Std. Deviation \\
\hline Female & 65 & 76.4421 & 12.35014 \\
Male & 63 & 80.8871 & 13.28885 \\
\hline
\end{tabular}

towards ESL substantially. This finding is in line with the earlier findings of reference [2] and in contrast with reference [13], [12] and [15] who established that attitudes of female learners are higher than those of male towards EFL learning. Regarding three aspects of attitudes, the mean score of males (26.3065) is relatively higher than females (25.5895) regarding behavioral attitude aspects. In Other two aspects (cognitive and emotional) also males have higher mean score accordingly (27.0323) and (27.5484) as compared to females (25.5895) and (25.2632). This descriptive analysis shows males attitude towards ESL comparatively higher than that of females.

This study aims at examining the attitude of students of the first semester at UOG, assuming that students have distinctive attitudes. Outcomes of current study contradict with the assumptions of heterogeneous attitudes of students. It supports the findings of reference [13] that students are not motivated to learn English. The present study also confirms the findings of a study of reference [14] regarding three aspects of attitude. Students have a negative attitude in term of behavioral, cognitive and emotional aspects of attitude. On the other hand, this study denies the works of reference [9] [10] [12]. According to these studies students have overall a positive attitude towards ESL learning. May be they are well aware of the significance of English that is why they are interested in learning English. The negative attitudes of SADA students at UOG might be related to their lack of awareness about the importance of English in their professional lives and their complete focus on practical work. Another reason may be they do not have any external motivation such as lack of instructor's encouragement [18], instructions given in native language and less use of English language in their classrooms.

\section{Conclusions}

This article reports on a study that examined the female and male students' attitude towards English as a Second Language regarding three aspects of attitude, i.e. behavioral, cognitive and emotional. Although, overall students have negative attitudes, but the mean scores of males in all aspects show that males have slightly higher attitudes towards ESL. The findings of the current study showed insignificant demographic (gender) difference. Gender does not regulate attitudes of ESL learners. Moreover, students of Architecture showed the least interest in learning the English language.

This study contributes to the existing literature on attitudes of Pakistani learners from the lens of artists. By providing insights into learners' attitudes, present work contributes to understanding EFL learning and teaching in Pakis- 
tan. Present study implies that teachers who teach English in SADA department should add some events to show explicitly the importance of English language so that students could be motivated to learn English as these students will have to develop their verbal communication in the English language to present their work at international level.

Moreover, as attitudes are not static, present research does not claim to capture a change in learners' attitude due to its limited scope. Besides, further research is needed to uncover the reasons and investigate the ways to enhance positivity in learners' attitude.

\section{References}

[1] Tavil, Z. (2009) Parental Attitudes towards English Education for Kindergarten Students in Turkey. Kastamonu Education Journal, 17, 331-340.

[2] Fakeye, D. (2010) Students' Personal Variables as Correlates of Academic Achievement in English as a Second Language in Nigeria. Journal of Social Sciences, 22, 205-211. https://doi.org/10.1080/09718923.2010.11892803

[3] Kara, A. (2009) The Effect of a 'Learning Theories' Unit on Students' Attitudes towards Learning. Australian Journal of Teacher Education, 34, 100-113. https://doi.org/10.14221/ajte.2009v34n3.5

[4] Bernaus, M. (2005) What Keeps Teaching Going? Motivation and Attitudes. Universitat Autònoma de Barcelona, Spain.

[5] Eagly, A.E. and Chaiken, S. (1993) The Psychology of Attitudes. Harcourt Brace, Orlando.

[6] Saidat, A.M. (2010) Language Attitude: The Case of Jordan. International Journal of Academic Research, 2, 235-243.

[7] Baker, C. (1992) Attitudes and Language. Multilingual Matters, Clevedon.

[8] Feng, R. and Chen, H. (2009) An Analysis on the Importance of Motivation and Strategy in Postgraduates English Acquisition. English Language Teaching, 2, 93-97. https://doi.org/10.5539/elt.v2n3p93

[9] Al Noursi, O. (2013) Attitude towards Learning English: The Case of the UAE Technology High School. Education Research Journal, 4, 21-27.

[10] Ahmad, S. (2015) Attitude towards English Language Learning among EFL Learners at UMSKAL. Journal of Education and Practice, 6, 6-15

[11] Harmer, J. (2002) How to Teach English. Longman, London.

[12] Eshghinejad, S. (2016) EFL Students' Attitudes toward Learning English Language: The Case Study of Kashan University Students. Cogent Education, 3, 1-13. https://doi.org/10.1080/2331186X.2016.1236434

[13] Abidin, D.M.J.Z., Pour-Mohammadi, M. and Alzwari, H. (2012) EFL Students' Attitude towards Learning the English Language: The Case of Libyan School Students. Asian Social Science, 8, 119-134.

[14] Youssef, A.M.S. (2012) Role of Motivation and Attitude in Introduction and Learning of English as a Foreign Language in Libyan High School. International Journal of Linguistics, 4, 366-373.

[15] Ghazvini, S.D. and Khajehpour, M. (2011) Attitude and Motivation in Learning English as Second Language in High School Students. Procedia Social and Behavioral Science, 15, 1209-1213. https://doi.org/10.1016/j.sbspro.2011.03.264 
[16] Yasmin, M., Sarkar, M. and Sohail, A. (2016) Exploring English Language Needs of Hotel Industry in Pakistan: An Evaluation of Existing Teaching Material. Journal of Hospitality \& Tourism Education, 28, 202-213. https://doi.org/10.1080/10963758.2016.1226846

[17] Yasmin, M., Sohail, A., Sarkar, M. and Hafeez, R. (2017) Creative Methods in Transforming Education Using Human Resources. Creativity Studies, 10, 145-158. https://doi.org/10.3846/23450479.2017.1365778

[18] Yasmin, M. and Sohail, A. (2017) Realizing Learner Autonomy in Pakistan: EFL Teachers' Beliefs about Their Practices. International Journal of English Linguistics, 8, 153-162. https://doi.org/10.5539/ijel.v8n2p153 